\title{
The Economic Impact of a Junior Club Sporting Event: Caravan Fans
}

\author{
Frank R. Veltri \\ Boise State University \\ Clay Daughtrey \\ Metropolitan State University Denver \\ John J. Miller \\ University of Southern Mississippi
}

\begin{abstract}
This study investigated the economic impact of visitor's expenditures at a junior girl's club sporting event in the city of Denver, Colorado. This study uses a random sample of 2,000 sport fans of which 1,163 surveys were found to be usable $(n=1,163)$. The findings reveal that hosting a club sports national tournament can generate substantial economic benefits and, in some cases, greater than those associated with mega sporting events. Key findings are that economic impact can play a critical role in assessing the potential benefits of hosting small events and that youth sport event managers must make sure to meet the needs of caravan fans. Caravan fans are the parents and family members that attend these events to watch their children participate.
\end{abstract}

Keywords: youth sporting event, economic impact, caravan fan

\section{INTRODUCTION}

The world of youth sports is changing. Gone are the days when young people predominantly organized themselves into pickup games and backyard contests. Cities throughout the United States fiercely compete to host youth sporting events to generate short-term economic growth (Bazzanella et al., 2020). While the number of youth sport contests has decreased due to the COVID-19 pandemic, the previous two decades revealed an increased number of incentives to host youth sporting events, including volleyball and baseball, which are now organized every weekend in urban and rural areas.

Many youth sporting events, as opposed to professional or Division I intercollegiate sports events, are considered small in scale. Gibson et al., (2003) that small-scale sporting events are "not simply related to the size of the event, but is also related to the fact that regular-season games do not tax the resources of the host city in the same manner as hosting a mega-event" (p. 182). Malchrowicz- Mośko and Poczta (2018) indicated that there is not a one size fits all reason to conduct small-scale events as each city can determine the strategy that best suits itself. Higham (1999) reported that small-scale sports events may generate positive impacts for host communities while avoiding the negative issues that are usually linked with largescale. Small-scale sports events generally involve little public funding, often operate using existing infrastructures, and are more able to control crowds and congestion that occur at mega sporting events 
(Malchrowicz-Mośko \& Poczta, 2018). Furthermore, Mondello and Rishe (2004) maintained that smallerscale events require less additional expenses compared to larger sporting events. Additionally, Matheson (2006) claimed that smaller sporting events are (a) less likely to induce a crowding-out effect, (b) carry fewer security costs, (c) cause fewer deviations from normal business patterns (supporting the idea that multiplier analyses are more accurate than for mega-events), and (d) cause fewer incentives to produce inflated results. Thus, small-sized sport events may have the potential to economically assist the local community (Kwiatkowski et al., 2017; Malchrowicz-Mośko \& Poczta, 2018).

Misener (2016) indicated that many cities have realized the economic boom that youth sport tourism can provide, making it a highly sought-after tool to determine the economic impact of the event. Deery et al., (2004) stated that "perhaps the most significant in terms of tourist numbers and economic impact" (p. 239). Furthermore, Chalip (2006) stated that the "rapid worldwide growth in the number of sports events has been driven largely by the economic impact that events are expected to generate" (p.109).

Irwin and Sandler (1998) indicated that sporting events may provide an economic impact due to the injection of new money into the local economy through expenditures in the areas of lodging, food and beverages, retail products, and other goods and services. However, economic impact analyses (EIA) offer 'best guesses' rather than absolute certainty (Crompton \& Lee, 2000). Chalip (2006) reported that "most events are not profitable per se, so they must be justified by their aggregate economic impact, which is claimed to offset any deficit in event earnings" (p. 2). Rogers (2007) stated, "All too often, the estimates are inaccurate at least in part because the manner in which information is collected and projected does not meet acceptable research standards" (p. 7). While Dwyer et al. (2006) also endorsed the criticisms of an EIA, they also contended that when smaller events take place, I-O analysis may be appropriate to assess local impact because the overestimations are "not likely to be too large at this level of analysis" (Dwyer et al., 2006, p. 61).

Despite the likelihood of offering a positive economic impact, little research has been conducted regarding the economic impact of small-scale, youth sporting events (Agha \& Taks, 2015; Kwiatkowski et al., 2017). This study provides valuable information for communities looking to host junior club sporting events. Understanding the impact of various travel expenditure patterns can be beneficial to local communities, cities, regions, and state destinations. Thus, the purpose of this study was to evaluate the economic impact of hosting a youth sporting event on the city of Denver, Colorado.

\section{LITERATURE REVIEW}

\section{Parental Financial Contributions}

Pierce et al., (2020) revealed that youth sports competitions are now heading in a positive direction as $76 \%$ of parents of youth participants reported being more comfortable traveling to competitions despite the continued presence of COVID-19. Additionally, Pierce et al., (2020) revealed that nearly $60 \%$ of the parents did not feel that the COVID-19 pandemic would negatively affect their sports travel budget. Thus, as vaccines take effect and precautions are continued, the number of youth sports events will probably continue to climb to previous heights in the near future.

Hyman (2012) reported that youth sports travel is one of the fastest-growing segments of the travel industry, outpacing leisure travel overall. Over two million children play club sports, and parents pay thousands of dollars for their children to be part of a club or traveling team in the United States (Harrison, 2019). Many of these traveling teams make multiple trips across the country to participate in club team tournaments, with several of them being sanctioned by national organizations and requiring membership dues. For example, to be a member of an elite volleyball club can run costs of up to $\$ 3,500$, with another $\$ 3,000$ required for travel. Hyman (2012) indicated that the costs of enrollment for playing on a private club team can be staggering. Parents can spend between $\$ 100$ and $\$ 500$ per month, per child, on elite youth club sports, with the bulk of the money going toward travel and team fees. However, even $\$ 1,000$ per month is not unheard of (Gigante, 2018). In addition, showcase tournaments can cost over $\$ 500$ for a weekend slate of three games. 
Smith and Trisdale (2012) cited a study conducted by the National Association of Sports Commissions that examined host cities' tournament participants by sending out hundreds of surveys to gather a thorough understanding of the participant demographics and spending habits. Smith and Trisdale (2012) recognized that since these are youth tournaments, most players are accompanied by at least one parent. The researchers found that $66 \%$ of the athletes had two parents with them, $50 \%$ had one or more siblings, $16 \%$ had one or more grandparents, and $14 \%$ had additional relatives joining them. The surveys revealed that each athlete competing in the tournaments brought 2.14 additional people with them. In combination, the weekend tournaments attracted 17,400 people, $80 \%$ of which traveled from outside the local area to take part in the tournament (Smith \& Trisdale, 2012). Drawing on the results of the survey, the researchers estimated average total spending of $\$ 985$ per non-local family attending either tournament, resulting in $\$ 3.4$ million in direct spending in the region.

For every child traveling to a club tournament, it is estimated that one or both parents, siblings, and grandparents will accompany the child (Schoettle, 2013). Furthermore, parents who travel to competitions to support their children will spend money on travel, food, and accommodations to support their participating children (Roush, 2005). For example, Coakley (2006) reported that hockey parents spent between $\$ 5000$ and $\$ 20,000$ annually on travel, equipment, hotel, and food, among other items to support their child's participation in the sport.

\section{Economic Impact Use}

A traditional rationale that communities may use to host an event is the overall economic impact (Brymer \& Schweitzer, 2017; Mules \& Faulkner, 1996). Economic impacts are influences in a community caused by a specific event or company, which affect various levels of economic activity. These influences, or impacts, are classified into three categories: direct, indirect, and induced (Ramchandani \& Coleman, 2012). Direct spending occurs there is an influx of dollars that come into a region during the first round of spending. Mondello and Rishe (2004) stated that direct spending is "the total dollar amount spent at games or events, as well as the amount spent for an entire stay (hotel rooms, food, local vehicle rental,...). Generally speaking, only money originating outside the local economy and spent within the local economy is considered economic impact..." (p. 332). For example, when fans come to a locale to watch a sporting event and they spend money on hotels, restaurants, entertainment, etc., their purchases have a positive impact on the businesses surrounding the team. When fans come from out of town, their purchases are viewed as new money entering the economic ecosystem, causing a community to grow. Indirect impacts occur during the second round of spending, as a result of direct spending (Ramchandani \& Coleman, 2012). For example, when the restaurant purchases wine from a local distributor to restock their supplies and the out-of-town individual to attend the sports event drinks the wine. Induced impacts occur in a community during subsequent rounds of spending (Ramchandani \& Coleman, 2012). For example, restaurant employees use their increased income to purchase more groceries with the extra money from the increased number of restaurant visitors who attend the sports event.

\section{Economic Impact Analysis Controversy}

An economic impact analysis, when performed properly, tracks and measures the transactions that take place during each round of spending, measuring what comes into the community, how many times it is spent among community members and businesses, and how quickly these dollars then leave the area (Crompton, 1995). However, after analyzing 20 sport economic impact studies, Crompton (1995) reported at least 11 misuses that resulted in a number of inaccurate narratives. Specifically, Crompton (1995) identified four elements that were wrongly used among the sport economic impact studies. First, the economic impact studies used sales rather than income multiplier. Second, there was an apparent misrepresentation of employment multipliers. Third, the economic studies included local participants. The fourth element was the failure to exclude "time-switchers" and "casuals." Time-switchers and casuals are visitors who would have spent their money without the event. As a result, the income created by their spending should not count towards the economic impact analyses (Crompton, 1995). 
Several years later, Crompton and Lee (2000) compared and contrast thirty different sport economic impact studies. A case in point revealed that a reported financial loss of $\$ 9,375$ from a softball tournament. However, the convention and visitors bureau revealed an economic gain of more than $\$ 525,000$ to the community for the same softball tournament. As a result, Crompton and Lee (2000) indicated that not only can economic impact studies offer increased potential to influence the procedures but may also legitimize the use of economic impacts to the community.

Hudson (2001) implemented a meta-analysis to examine the misuse of economic impact analysis conducted on professional sports teams. Unsurprisingly, many of these studies committed the abuses identified earlier by Crompton (1995). Specifically, the most common violation was using gross rather than net impacts, with other studies using inflated multipliers. Taken together, these abuses overestimated the economic impact of the sports teams examined. However, despite the dangers of negative application of the impacts, if they are done properly with no manipulation or software such as IMPLAN is used, an economic impact can be an effective tool (Grix et al., 2017).

\section{Economic Impact of Youth Club Sporting Events}

While concerns have been raised about the viability of conducting economic impact analyses on sporting events as well as the recent COVID-19 pandemic, there have been some studies that have incorporated all of the required elements. For example, according to an economic impact formula created by Ryan Brewer at Indiana University-Purdue University, sports spectators spent approximately \$6.4 million between shopping, dining, and lodging in the Columbus, Ohio area during 2020 despite COVID19 restrictions (Staff Reports, 2020). In Vicksburg, Mississippi during 2019, the Convention and Visitors Bureau estimated a total economic impact of \$24 million. In an interview, the deputy director of the Vicksburg Convention and Visitors Bureau the growth could be attributed to "The majority of the activities at the Sports Force Parks on the Mississippi are for youth tournaments" (Gillette, 2019, para. 3).

Greensboro, North Carolina, hosted the National Soccer Series Girls Showcase, which was estimated to have a $\$ 6.1$ million economic impact on the area. It was also estimated that 20,000 fans traveled from 34 different states to watch and cheer their daughters on to victory while spending money in the city of Greensboro (Roush, 2005). Marc Bush, president of the Greensboro Sports Commission, "From an economic standpoint, it's as big as an Atlantic Coast Conference basketball tournament" (Roush, 2005, para. 7). Such a statement is significant as the Atlantic Coast Conference basketball tournament that was held in Greensboro reported an economic impact of \$13.6 million.

In another youth sporting event, the Capital Sports Volleyball Tournament, in Indiana, an estimated 30,000 visitors and 10,000 players visited the state. The economic impact of the event was estimated to be \$21.5 million economic impacts, which was larger than the estimated economic impact of \$19 million for the Big Ten Football Championship at Lucas Oil Stadium in Indiana (Schoettle, 2013). Thomas (2009) reported that the city of Chattanooga, Tennessee, capitalized on girls sporting events when they unveiled an \$11.8 million softball complex, aimed at hosting the National Softball Tournament. The event drew 232 teams and roughly 7,500 fans, and the city estimated that visitors spend about $\$ 3.6$ million for the week (Thomas, 2009).

The city of Westfield, Indiana, invested $\$ 85$ million in the Grand Park project to bring national and regional sporting tourism to the area. The city's Grand Park soccer and baseball project was touted as the largest sports complex in the United States. City officials estimated the project to draw an estimated 400,000 visitors annually, and it has seen an economic impact of over $\$ 700$ million on the surrounding areas (Schoettle, 2013).

More recently, the 2017 United States Youth Soccer Region II (Midwest) Championships provided an estimated economic impact of $\$ 17$ million to Sioux Falls, South Dakota (Rael, 2017). The breakdown of the economic impact was approximately $\$ 10$ million in direct spending and $\$ 7$ million in indirect spending. The estimated economic impact considered more than 4900 players, coaches, and tournament officials that ate at the local restaurants bought apparel at the local retail stores and stayed in local hotels over the sixday event (Rael, 2017). 


\section{Purpose of the Study}

Previous research has indicated that smaller sporting events might have a more positive economic impact on host communities than large mega sporting events (Agha \& Rashcher, 2012, Veltri et al., 2009). Additionally, youth sports, in particular, tend to attract many out-of-town visitors who infuse "new" money into the economy of a host community (Case et al., 2013. In an interview, Mark Bush further stated that youth sports such as girls' soccer tournaments spend money and bring along the most people (Roush, 2005). However, many junior club event organizers and community tourism organizations frequently do not have quantifiable information related to the expenditure patterns of sports fans and/or estimates of the economic impacts of club sporting events. Thus, the purpose of this study was to evaluate the economic impact of hosting a national youth volleyball sporting event involving multiple matches over a three-day weekend in the city of Denver, Colorado.

\section{METHODOLOGY}

\section{Procedures}

Several weeks before the investigation, the organizers of the Crossroads Junior National Qualifier Volleyball Tournament were contacted to obtain permission to conduct the study during the tournament. After meeting with the organizers to clarify the purpose and importance of the study on the community, the authors received approval. Amongst the areas of discussion was the use of the survey instrument.

Surveying actual visitors is the most straightforward method to obtain visitors' spending data (Wilton \& Nickerson, 2006). Lovejoy (2003) explained the process, as follows:

The best way to measure the impact of visitor spending is to use surveys to determine the amount and type of goods that travelers tend to purchase, and then to estimate the portion of output visitors support in key industries (p. 7).

To make certain that the survey instrument was valid, content validity was employed. Since content validity is dependent on expert judgment regarding the appropriateness of the content (Andrew et al., 2011), threesport event managers were asked for input. After examining the instrument, four grammatical changes were suggested by the selected experts in the field of economic impact studies. Once these suggestions were incorporated into the instrument, all of the selected experts viewed and approved the content of the instrument as appropriate.

The subsequent step was to determine the reliability of the instrument. Reliability addresses the consistency of the research findings' quantitative results (Litwin, 1995). To ensure that the survey questionnaire was reliable, three individuals, who had previously conducted small-scale sporting events but were not involved in determining instrument validity, were asked for their inputs. As test-retest reliability is the most common method used to determine survey instrument reliability (Litwin, 1995), this method was adopted for the present study as well. The result of the pilot study was $\alpha=.84$, which is above the criteria of establishing reliability (Andrew et al, 2011). Thus, the questionnaire was deemed to possess sufficient validity and reliability to continue the investigation.

To alleviate the concerns expressed by Crompton (1995) regarding the misuse of spectator residence, the researchers determined that only expenditures of respondents outside of the zip codes associated with the Denver Metropolitan Area) would be counted as new money brought into a defined economic region. Defining locals is critical in the EI process as they should not be included in further EI modeling because they do not circulate new money within the local economy (Crompton, 2006; Crompton, et al., 2001). Locals were defined as individuals who resided within the immediate local community zip, while nonlocals were deemed as individuals who lived outside the immediate local community zip code area (Crompton, et al., 2001). Additionally, using the zip codes provided anonymity for the respondents.

In addition, other attendee profiles can and should be used for further EIA (Wynen, 2013). The questionnaire included information about the spectators' role in the event (e.g., family member, friend, volleyball fan, etc...) as well as the purpose of visit in the city to ensure that their primary purpose was to 
attend the volleyball tournament. The respondents were also asked to provide an estimation of the spending habits of their party during the visit including the admission fee to the event. Additionally, the cost of food (breakfast, lunch, and supper or event concession), shopping (sports apparel, non-sport apparel, and souvenirs) as well as any costs of entertainment such as attending movies or plays were included in the questionnaire. Moreover, the respondents were asked to indicate the length of stay (number of nights and approximate cost of lodging per night) and the amount of money spent on gas or car rental to attend the event. These survey questions are in line with questions typically employed in similar studies (Taks, et al., 2011).

\section{Survey Procedures}

An economic study requires carefully sampled "stints" (Rogers, 2007) and trained personnel to intercept attendees throughout the event. A such, students from a nearby major university were carefully trained and placed at pre-determined spots throughout the tournament facility. Following Bernthal and Regan's (2004) methodology, the volunteers were instructed to intercept one person per party as they passed through the turnstiles and asked the spectators if they would be willing to complete the questionnaire. The spectators were intercepted on the second day of their travels which provided assurance that had expenditures in the Denver Metropolitan Area as a result of attending the tournament. Spectators were given a brief explanation of the purpose of the study and were assured that responses would be completely anonymous and confidential. Data were collected at the event because visitors were prone to inflating their reported expenditures if enough time had elapsed between spending and recalling (Zhou, 2000).

According to Turco (1997), field researchers should seek a party "decision-maker" to provide information on the visitor groups' expenditures. A party, in this context, was defined as a group of individuals who travel in the same vehicle or stay in the same room when requiring housing. It is essential that when recording party expenditure figures on the surveys that the respondent and the researcher are in precise agreement in identifying total costs (VanBlarcom, 2007). The party concept is very appropriate for families where one adult person is responsible for identifying the expenditures and therefore can provide accurate estimates of spending for the group as a whole. Additionally, the one-party interception strategy was employed was to reduce duplication (double-counting) of spending expenditures (Ryan \& Glendon, 1998; Wilton \& Nickerson, 2006). Double counting is a notorious cause of the overestimation of visitor spending and is particularly important when considering expenditures (Ryan \& Glendon, 1998). As such, no group or individual was surveyed more than once. Using this method, 2,000 surveys were distributed to the spectators with 1,165 (58\% response rate) surveys were considered useable.

There were approximately 25 minutes between matches, thereby providing the respondents enough time to complete the survey and return it to the researcher. The first pages of the survey explained the study and respondents' ethical rights (Taks et al., 2011). Respondents were instructed to return the completed survey to the researcher, and they were given a numbered ticket for a random draw for a $\$ 50$ Starbucks gift card. The winner was announced, and the winning number was posted at the registration booth during the last day of the tournament.

\section{RESULTS}

\section{Demographics}

An overview of the findings indicated that $653(56 \%)$ respondents were female while $512(44 \%)$ were males. One thousand seventy $(92 \%)$ of the respondents revealed the primary reason for the trip was to watch at least one of their children participate in the tournament. Concerning the group sizes, $418(36 \%)$ had three to four members, $348(30 \%)$ had five to six members. Regarding the number of nights the respondents stayed in a hotel while attending the volleyball tournament, $57 \%$ stayed for a minimum of three nights while $35 \%$ stayed for more than three nights. Nearly $75 \%$ of the respondents reported that the total annual household income was $\$ 70,001$ or more. Finally, 727 (63\%) indicated that they attended one to two youth volleyball tournaments to watch at least one child during the year while $410(35 \%)$ also attended a volleyball tournament to support their child at a youth volleyball tournament (see Table 1). 
TABLE 1

RESPONDENT DEMOGRAPHICS

\begin{tabular}{|c|c|c|}
\hline & $\mathrm{n}$ & $\%$ \\
\hline \multicolumn{3}{|l|}{ Gender } \\
\hline Female & 653 & 56 \\
\hline Male & 512 & 44 \\
\hline \multicolumn{3}{|c|}{ Primary Reason for the Trip was to Attend Volleyball Tournament } \\
\hline Yes & 1,070 & 92 \\
\hline No & 95 & 8 \\
\hline \multicolumn{3}{|l|}{ Group Size } \\
\hline $1-2$ people & 221 & 19 \\
\hline 3-4 people & 418 & 36 \\
\hline 5-6 people & 348 & 30 \\
\hline More than six people & 178 & 15 \\
\hline \multicolumn{3}{|c|}{ Number of Nights Stayed in Host City for the Tournament } \\
\hline 1 night & 24 & 3 \\
\hline 2 nights & 67 & 8 \\
\hline 3 nights & 669 & 57 \\
\hline \multicolumn{3}{|c|}{ Total Annual Household Income } \\
\hline$\$ 40,000$ or below & 61 & 5 \\
\hline$\$ 40,001-\$ 50,000$ & 189 & 16 \\
\hline$\$ 50,001-\$ 60,000$ & 119 & 10 \\
\hline$\$ 60,001-\$ 70,000$ & 286 & 25 \\
\hline$\$ 70,001-\$ 80,00$ & 378 & 32 \\
\hline More than $\$ 80,000$ & 485 & 42 \\
\hline \multicolumn{3}{|c|}{ Number of Youth Volleyball Tournaments Attended } \\
\hline $1-2$ tournaments & 7 & 63 \\
\hline $3-4$ tournaments & 410 & 35 \\
\hline More than 4 tournaments & 28 & 2 \\
\hline
\end{tabular}

\section{Economic Impact Data Analysis}

The researchers of this study used IMPLAN software to calculate the economic impact on the Denver Metro Area. IMPLAN software was originally designed to determine economic impacts rather than economic contributions (IMPLAN, 2015). The IMPLAN model estimated the increase in economic activity associated with money injected into a community by visitor's expenditures into the economy. Additionally, the IMPLAN model provides unbiased multiplier estimates at the county level of aggregation for up to 509 industries through a series of equations relating local economic spending to total regional production (IMPLAN, 2015). Such estimates provide the best approximations to actual impact multipliers using actual and estimated local information.

Frechtling (1994) suggested that IMPLAN was a cost-effective way to measure total tourism impacts on an area's economy. While the economic interlinkage of industry sectors can be estimated using inputoutput production matrices, IMPLAN software and data are often used in economic impact studies (Parajuli et al., 2018). IMPLAN software is frequently employed to quantify indirect spending (i.e., purchases from 
supporting industries) and induced spending (i.e., employee household spending) that result from the original economic activity (Parajuli et al., 2018).

\section{Economic Impact Results}

Chhabra et al., (2002) indicated that an important variable in the economic analysis of any sporting event is the expenditure patterns of non-local residents in the local area. As recommended by previous research (Crompton et al., 2001; Robinson \& Gammon, 2004), only expenditures of non-local residents of the Denver Metropolitan Area, whose primary purpose was to attend the event, were analyzed for this study. The non-resident respondents stayed in the area for an average of four days and 3.35 nights.

A final area highlighted by the study findings pertains to family group spending during their visit to the Crossroads Junior National Qualifier Volleyball Tournament. It was important to consider restaurants, concessions, and beverages per day (\$268.00), followed by car rental per day (\$33.47) and apparel shopping (\$58.43) as well as entertainment, souvenirs, retail, facility concessions, and other expenses (i.e., parking). The accommodation was the category associated with the highest level of spending ( $\$ 188.00$ per night). The average visitor's party size was 3.43 people, which did not include youth players.

Table 2 shows the estimated income injected into the Denver Metropolitan Community from visiting spectators. Expenditures at restaurants, including food and beverages, were estimated at \$5,670,192. Lodging usage during the two weekend periods in the city of Denver was estimated at $\$ 5,470,829$. Entertainment, outside of the tournament, was approximated at $\$ 2,684,876$. To clarify, entertainment was money spent on movies, theater, museums, etc... from non-local individuals. Retail shopping in the host city accounted for $\$ 2,032,212$ while money spent by non-locals on team/tournament apparel, concessions, and souvenirs purchased at the tournament was estimated to be $\$ 1,832,039$. Spending money on groceries during the tournament was approximated to be $\$ 1,098,957$. Finally, renting a car during the tournament was $\$ 1,154,382$, which did not include $\$ 21,348$ to purchase gas and parking. As a result, the IMPLAN software (which took into account the regional multiplier and administrative costs to conduct the event) estimated total non-local visitors' direct spending economic impact on the community to be $\$ 19,955,835$ million.

TABLE 2

ESTIMATED NEW INCOME INJECTED INTO THE COMMUNITY DURING THE CROSSROADS NATIONAL VOLLEYBALL QUALIFIER TOURNAMENT

\begin{tabular}{|l|l|l|}
\hline & $\begin{array}{l}\text { Average Expenditure } \\
\text { per Day }\end{array}$ & $\begin{array}{l}\text { Total New } \\
\text { Revenue }\end{array}$ \\
\hline Restaurant (e.g. food and beverages) & $\$ 113.99$ & $\$ 5,670,192$ \\
\hline Lodging & $\$ 188.00$ & $\$ 5,470,829$ \\
\hline Entertainment (e.g., movies, theater, city tours, etc) & $\$ 66.75$ & $\$ 2,684,876$ \\
\hline Retail Shopping in Host City & $\$ 45.98$ & $\$ 2,023,212$ \\
\hline Apparel, Concession, Souvenirs & $\$ 39.35$ & $\$ 1,832,039$ \\
\hline Grocery Shopping & 24.98 & $\$ 1,098,957$ \\
\hline Car Rental & 33.53 & $\$ 1,154,382$ \\
\hline Gas and Parking & 35.11 & $\$ 21,348$ \\
\hline Total: & & $\mathbf{\$ 1 9 , 9 5 5 , 8 3 5}$ \\
\hline
\end{tabular}

*Note all of the above relate to items purchased in the host city during the tournament over 3.5 days

\section{DISCUSSION}

The economic turmoil wrought by COVID-19 has touched nearly every component of American life, including youth sports. For many cities, business and convention travel has decreased significantly over the past couple of years, while sports travel has remained consistent or increased (Roush, 2005). However, the 
results of this study indicated that parents of youth volleyball players had attended multiple tournaments. This result supports Pierce's (2020) contention that travel to youth sporting events is beginning to increase. City and business leaders realized that youth sporting events deserve to be recognized as legitimate engines of economic activity, often with relatively modest up-front investments.

Many youth tournaments last for 2-3 days so that teams can have multiple games and compete in championships. This ensures that the players and their families stay in the region for multiple nights (Smith \& Trisdale, 2012). Thus, this study intended to provide an estimate of the potential economic impact generated by hosting a national female club sports tournament in a large metropolitan community. The results can provide communities and travel team programs information on the economic impact of hosting an event and support the idea that sports travel, or "sportcation," can generate increased revenues to the city or region.

Apart from identifying the economic behaviors of attendees at a small-scale sports event, the scientific value of the article deals with the socio-demographic characteristics of the respondents. As Ritchie (2004) indicated that profiling attendees at small-scale sporting events can offer an awareness into the market segments. Thus, small sports events have been increasingly used in the marketing of cities (MalchrowiczMośko \& Poczta, 2018). As such small-sized events offer cities opportunities to generate a marketing strategy to promote city or regional tourism (Csobán \& Serra, 2014; Veltri et al., 2009).

According to Crompton and Lee (2000), communities often assume that sporting events will attract more outside visitors, resulting in new money being injected into the community. Many of these visitors are affluent, well-educated professionals (Smith, \& Trisdale, 2012). The results of the present study indicate that private sports clubs that host sporting events can attract a significant number of visitors and participants and that their combined expenditures increase the economic impact of the event considerably. The results indicated that over \$20 million of new money was brought into the Denver Metropolitan Area over two weekends due to the Crossroads Junior National Qualifier Volleyball Tournament. As such, hosting a youth event may be a consideration that brings people to a city they may not otherwise visit.

Visitors attending the tournament typically engaged in more than one activity on their visit to Denver. Food and restaurant expenditures were recognized as the greatest contribution to the local economy, accounting for $26 \%$ of all new expenditures. Hotel accommodations followed closely behind, accounting for $25 \%$ of expenses by visitors. These results are consistent with festival and event studies of short-term events (Crompton \& Lee, 2000; Hjerpe \& Kim, 2007). Interestingly, entertainment and shopping expenditures accounted for $19 \%$ of the economic impact in the area. In a previous study, Carlson et al. (2014) indicated that shopping and entertainment are key elements of revenue generation for any sized city. Additionally, Veltri et al. (2009) reported that shopping and entertainment were the primary expenditures for outside visitors while attending a club sporting event. Thus, small-scale youth events may offer an option to the standardized, commercial-oriented, and costly larger sporting events to contribute to sustainable development and increased economic impact to the regions.

As they completed the questionnaire, many parents spoke of personal and family sacrifices that were made so their child could participate in tournaments. While not necessarily financial, the primary point was that parents take the time to travel and attend their daughters' competitions regularly. The results of this study indicated that over $90 \%$ of the respondents were parents of a tournament participant and often traveled to the tournaments to watch at least one child play. Additionally, many of the respondents traveled to tournaments and often ate at the same restaurants with the families of teammates. Due to the way they travel and interact from tournament to tournament with other team families, a number of the respondents felt as though they were "part of a caravan." Several authors have emphasized the importance of friends and relatives as a key market for event sport tourism (Bull \& Weed, 2009; Hinch \& Higham 2011; Gibson, et al., 2012). Thus, the authors of this article propose that the term "caravan fans" be used to describe parents who attend sports events and provide emotional and financial support to a child participating in the tournament club.

Small-scale sports events provide opportunities for sustainable tourism development for several reasons. First, small-scale sports events usually do not have to compete for the rights to organize as do mega-events (e.g., Olympics, Super Bowl, etc..). A second reason relates to the ability of the host city to 
use the existing sports infrastructure. Third, since the site of Crossroads Junior National Qualifier Volleyball Tournament has been consistently in Denver, Colorado the host committee has had experience in organizing the event. Thirdly, sports such as youth volleyball sporting events are built on loyalty to the events, which may equate to destination loyalty. Spectators such as mothers, fathers, and other family members may attend events several times which may create a desire to return as a tourist. Such desire to return to the area cannot be developed by organizing mega sporting events, such as the Olympics, as they always take place in various parts of the world. As such, cities should be aware of the growing hidden value of hosting national, private club sporting events and other such events. Private club sporting events at either the national or regional levels are powerful attractions that may provide an excellent opportunity to generate caravan fan interest and offer value-added spectatorship and tourism.

\section{CONCLUSION}

Economic impact studies play a critical role in assessing the potential benefits of hosting both mega and small events. The results of this study reveal the possibility of a positive economic impact of conducting small-scale sports events. It is hoped that results may inspire others to more fully consider conducting smallscale sporting events that could successfully impact an economic revival from the COVID-19 pandemic as well as improvement of the city's image. Most cities, regions, and states planning to bid and host a private club sporting event should research the economic impact that the event can generate. Our study shows that when selecting a sporting event to host, a city, region, or state can't go wrong with a private club sport event. Moreover, this research provides support for Daniels' (2007) finding that youth sports tend to generate a positive economic impact on local communities. Spectator business from the Crossroads National Volleyball Qualifier Tournament reverberated throughout the Greater Denver Metropolitan Area in terms of jobs, wages, supply chain purchases, and taxes. All the spectators had a direct spending impact of over \$22 million. Finally, because so many families attended the youth volleyball tournament, many from outside of Denver may choose to vacation there or a nearby site. As a result, future tourism may increase due to the area as a result of the youth volleyball tournament. Therefore, the Crossroads Junior National Qualifier Volleyball Tournament should continue its long-term relationship with the city of Denver. As tournament directors prepare the next proposal to attract a private club team, they can almost be assured that caravan fans will follow the event and contribute to the economic impact of their city, region, and state.

\section{REFERENCES}

Agha, N., \& Taks, M. (2015). A theoretical comparison of the economic impact of large and small events. International Journal of Sport Finance, 10(3), 199-216

Andrew, D.P.S., Pedersen, P.M., \& McEvoy, C.D. (2011). Research Methods and Design for Sport Management. Human Kinetics Publishing.

Bazzanella, F., Peters, M., \& Schnitzer, M. (2019, August). The perceptions of stakeholders in small-scale sporting events. Journal of Convention \& Event Tourism, 20(4), 261-286.

Bernthal, M., \& Regan, T. (2004). The economic impact of a NASCAR racetrack on a rural community and region. Sport Marketing Quarterly, 13(1), 26-34.

Brymer, E., \& Schweitzer, R.D. (2017). Phenomenology and extreme sports experience. Routledge.

Bull, C., \& Weed, M. (2009). Sports tourism: Participants, policy and provider (2nd ed.). Routledge Publishing.

Carlson, J.A., Sallis, J.F., Kerr, J., Conway, T.L., Cain, K., Frank, L.D., \& Saelens, B.E. (2014). Built environment characteristics and parent active transportation are associated with active travel to school in youth age 12-15. British Journal of Sports Medicine, 48(22), 1634-1639.

https://doi.org/10.1136/bjsports-2013-093101 
Case, R., Dey, T., Lu, J., Phang, J., \& Schwanz, A. (2013, January). Participant spending at sporting events: An examination of survey methodologies. Journal of Convention \& Event Tourism, 14(1), $21-41$.

Chalip, L. (2006). Towards social leverage of sport events. Journal of Sport \& Tourism, 11(2), 109-127.

Chhabra, D., Sills, E., \& Rea, P. (2002). Tourist expenditures at heritage festivals. Event Management, 7 , 221-230. https://doi.org/10.3727/152599502108751613

Coakley, J. (2006). The good father: Parental expectations and youth sports. Leisure Studies, 25(2), $153-$ 163. https://doi.org/10.1080/02614360500467735

Colorado Crossroads - USA Volleyball National Qualifier. (n.d.). Retrieved from https://coloradocrossroads.org/

Crompton, J.L. (1995). Economic impact analysis of sports facilities and events: Eleven sources of misapplication. Journal of Sport Management, 9(1), 14-35.

Crompton, J.L. (2006). Economic impact studies: Instruments for political shenanigans? Journal of Travel Research, 45(1), 67-82.

Crompton, J.L., \& Lee, S. (2000). The economic impact of 30 sports tournaments, festivals, and spectator events in seven U.S. cities. Journal of Park and Recreation Administration, 18(2), 107-126.

Crompton, J.L., Lee, S., \& Shuster, T.J. (2001). A guide for undertaking economic impact studies: The Springfest example. Journal of Travel Research, 40(1), 79-87.

Csobán, K.V., \& Serra, G. (2014). The role of small-scale sports events in developing sustainable sport tourism-A case study of fencing. Applied Studies in Agribusiness and Commerce, 8(4), 17-22.

Daniels, M.J. (2007). Central place theory and sport tourism impacts. Annals of Tourism Research, 34(2), 332-347. https://doi.org/10.1016/j.annals.2006.09.004 [Google Scholar], [ScienceDirect].

Deery, M., Jago, L., \& Fredline, L. (2004). Sport tourism or event tourism: Are they one and the same? Journal of Sport \& Tourism, 9(3), 235-245.

Duglio, S., \& Beltramo, R. (2017). Estimating the economic impacts of a small-scale sport tourism event: The case of the Italo-Swiss mountain trail CollonTrek. Sustainability, 9(3), 343-360.

Dwyer, L., Forsyth, P., \& Spurr, R. (2006). Assessing the economic impacts of events: A computable general equilibrium approach. Journal of Travel Research, 45, 59-66.

Frechtling, D.C. (1994). Assessing the economic impacts of travel and tourism - Measuring_economic benefits. In B.J.R. Ritchie \& C.R. Goeldner (Eds.), Travel, Tourism and Hospitality_Research (2nd ed., pp. 367-392). John Wiley and Sons.

Gibson, H., Willming, C., \& Holdnak. A. (2003). Small-scale event sport tourism: Fans as tourists. Tourism Management, 24(2), 181-190. https://doi.org/10.1016/S0261-5177(02)00058-4

Gibson, H.J., Kaplanidou K., \& Kang, S.J. (2012). Small-scale event sport tourism: A case study in sustainable tourism. Sport Management Review, 15(2), 160-170.

https://doi.org/10.1016/j.smr.2011.08.013

Gigante, S. (2018, June 24). Cost of youth sports: Dollars and sense. Retrieved from http://blog.massmutual.com/post/cost-of-youth-sports-dollars-and-sense

Gillette, B. (2019, July 12). Youth sports tourism a home run. Sports Force Parks. Retrieved from https://sportsforceparks.com/news/youth-sports-tourism-a-home-run

Grix, J. (2012). Image leveraging and sport mega - events: Germany and the 2006 FIFA World Cup. Journal of Sport and Tourism, 17(4), 289-312. https://doi.org/10.1080/14775085.2012.760934

Grix, J., Brannagan, P.M., Wood, H., \& Wynne, C. (2017). State strategies for leveraging sports megaevents: Unpacking the concept of 'legacy'. International Journal of Sport Policy and Politics, 9(2), 203-218.

Harrison, S. (2019, June 28). Want your kid to play pro soccer? Sign her up for basketball. Retrieved from https://www.wired.com/story/want-your-kid-to-play-pro-soccer-sign-her-up-for-basketball/

Hinch, T.D., \& Higham J.E. (2011). Sport tourism development. Channel View Publication.

Hjerpe, E.E., \& Kim, Y. (2007). Regional economic impacts of Grand Canyon River runners. Journal of Environmental Management, 85(1), 137-149. https://doi.org/10.1016/j.jenvman.2006.08.012 
Hyman, M. (2012). The most expensive game in town. The rising cost of youth sports and the toll on today's families. Beacon Press.

IMPLAN. (2015). Summary description of the trade data methods available in IMPLAN. Retrieved from http://implan.com

Irwin, R.L., \& Sandler, M.A. (1998). An analysis of travel behaviour and event-induced expenditures among American collegiate championship patron groups. Journal of Vacation Marketing, 4(1), 78-90. https://doi.org/10.1177/135676679800400107

Kwiatkowski, G., \& Oklevik, O. (2017). Primary economic impact of small-scale sports events. Event Management, 21, 269-280.

Litwin, M.S. (1995). How to measure survey reliability and validity. SAGE Publications.

Lovejoy, K. (2003). Putting out the welcome mat: How big is the tourism industry? Regional Review, Q2, $6-13$.

Malchrowicz-Mośko, E., \& Poczta, J. (2018). A small-scale event and a big impact—Is this relationship possible in the world of sport? The meaning of heritage sporting events for sustainable development of tourism-Experiences from Poland. Sustainability, 10(11), 4289-4308.

Matheson, V.A. (2006). Is smaller better? A comment on "comparative economic impact analyses" by Michael Mondello and Patrick Rishe. Economic Development Quarterly, 20(2), 192-195.

Misener, L. (2016). Leveraging parasport events for community participation: Development of theoretical framework. European Sport Management Quarterly, 15(1), 132-154. https://doi.org/10.1080/16184742.2014.997773

Mondello, M.J., \& Rishe, P. (2004). Comparative economic impact analyses: Differences across cities, events, and demographics. Economic Development Quarterly, 18(4), 331-342. https://doi.org/10.1177/0891242404269505

Mules, T., \& Faulkner, B. (1996). An economic perspective on special events. Tourism Economics, 2(2), $107-117$.

Parajuli, R., Henderson, J. E., Tanger, S., Joshi, O., \& Dahal, R. (2018). Economic contribution analysis of the forest-product industry: A comparison of the two methods for multisector contribution analysis using IMPLAN. Journal of Forestry, 116(6), 513-519.

Pierce, D., Stas, J., Feller, K., \& Knox, W. (2020). COVID-19: Return to youth sports: Preparing sports venues and events for the return of youth sports. Sports Innovation Journal, 1, 62-68.

Rael, C. (2017, May 10). US Youth soccer has massive economic impact. Retrieved from https://www.soccertoday.com/us-youth-soccer-has-massive-economic-impact

Ramchandani, G.M., \& Coleman, R.J. (2012). Testing the accuracy of event economic impact forecasts. International Journal of Event and Festival Management, 3(2), 188-200.

Robinson, T., \& Gammon, S. (2004). A question of primary and secondary motives: Revisiting and applying the sport tourism framework. Journal of Sport Tourism, 9(3), 221-233. https://doi.org/10.1080/1477508042000320223

Rogers, J. (2007). Guidelines: Survey procedures for tourism economic impact assessments of gated events and festivals. Retrieved from http://www.mtc.gov.on.ca/en/research/ resources/Guidelines_Econ_Impact_Gated_Events_2007.pdf

Ross, S.D. (2001). Developing sports tourism - An éguide for destination marketers and sports events planners. National Laboratory for Tourism and eCommerce.

Roush, C. (2005, January). Cities get a kick out of soccer tournaments. Business North Carolina. Retrieved from https://businessnc.com/cities-get-a-kick-out-of-soccer-tournamentscategory/

Ryan, C., \& Glendon, I. (1998). Application of leisure motivation scale to tourism. Annals of Tourism Research, 25(1), 169-184.

Schoettle, A. (2013, September 23). Dream teams for tourism industry. Indianapolis Business Journal. Retrieved from https://www.ibj.com/articles/43672-dream-teams-for-tourism-industry

Smith, S.B., \& Trisdale, A. (2012, September 18). Game on! The impact of youth sports on a regional economy. Traverse City Area Chamber of Commerce. Retrieved from 
https://www.sportsdestinations.com/management/economics/game-youth-sports-regionaleconomy-12224

Staff Reports. (2020, September 27). Youth sports have massive impact on county. The Republic. Retrieved from http://www.therepublic.com/2020/09/30/youth_sports_have_massive_impact_on_county/

Taks, M., Chalip, L., \& Green, B.C. (2015). Impacts and strategic outcomes from non-mega sport events for local communities. European Sport Management Quarterly, 15(1), 1-6. https://doi.org/10.1080/16184742.2014.995116

Taks, M., Kesenne, S., Chalip, L., \& Green, B.C. (2011). Economic impact analysis versus cost benefit analysis: The case of a medium-sized sport event. International Journal of Sport Finance, 6, 187203.

Thomas, K. (2009, July 29). Girls' sports pack economic punch. The New York Times. Retrieved from https://www.nytimes.com/2009/07/29/sports/29softball.html

Turco, D.M. (1997). Measuring the economic and fiscal impact of state high school sport championship. Sport Marketing Quarterly, 6, 49-53.

VanBlarcom, B. (2007). Assessing the economic impact of sport/recreation/cultural events and facilities. Retrieved from http://66.102.1.104/scholar?hl=en\&lr=\&q=cache:bo6Ibr6JVoAJ:avesta.ns.ca/assets/pdfsppts/imp act_guide.pdf + Marsh, + J. + S. $+(1984) .+$ The + economic + impact + of + a + sm all + annual + sport + event

Veltri, F.R., Miller, J., \& Harris, A. (2009). Club sport national tournament: Economic impact of a small event on a mid-size community. Recreational Sports Journal, 33, 119-128. https://doi.org/10.1123/rsj.33.2.119

Wilton, J.J., \& Nickerson, N.P (2006). Collecting and using visitor spend data. Journal of Travel Research, 45, 17-25. https://doi.org/10.1177/0047287506288875

Zhou, Z. (2000). The impact of memory on expenditures recall in tourism conversion studies. Journal of Travel Research, 38(3), 303-7. https://doi.org/10.1177/004728750003800314 